\title{
Larisa Kocic
}

\section{Predestination in Milton's Paradise Lost and De Doctrina Christiana}

\section{Reply to Paul R. Sellin}

\begin{abstract}
In 1992 William B. Hunter challenged Milton's authorship of the heterodox treatise De Doctrina Christiana. The mainstream of the debate following it was faithfully recorded on the pages of the Studies in English Literature but there were a number of articles published in both Milton Studies and Milton Quarterly that added to the discussion of the treatise's provenance. In this paper I aim to develop the issue of predestination in the above-mentioned debate based on Paul R. Sellin's article "Milton's Paradise Lost and De Doctrina Christiana on predestination." In his article, Sellin tries to maintain Hunter's assumption that Milton could not have been the author of the treatise, by demonstrating a discrepancy between De Doctrina Christiana and Paradise Lost in the matter of predestination. I, on the contrary, hoped to show by detailed analysis the uncanny resemblance between the two works regarding predestination, especially when observed from a broader perspective of the doctrine of grace.
\end{abstract}

The discovery of a heterodox theological treatise in 1825 , later known as De Doctrina Christiana, ${ }^{1}$ had all the potential to reshape the face of the contemporary Milton studies changing the orthodox image of the great English poet into a heretic, or at least into a mind with quite extreme theological assumptions. Yet despite its possibilities, the treatise, immediately identified as Milton's long lost "Body of Divinity," ${ }^{2}$ was not exploited to its fullest ${ }^{3}$ until Maurice Kelley's book The Great

1. Henceforth De Doctrina.

2. A reference title given by Milton's Anonymous Biographer. See Maurice Kelley, The Great Argument: A Study of Milton's "De Doctrina Christiana” as a Gloss upon "Paradise Lost” (Princeton: Princeton University Press, 1942), p. 10.

3. Michael Lieb notes David Masson's saying in 1880, some fifty years after De Doctrina's discovery, that the treatise "seems to have found few real readers" (Michael Lieb, “De Doc-

The AnaChronisT (2003) 65-84 ISSN 1219-2589 
Argument was published in 1942. It was Kelley's great argument that founded De Doctrina's reputation as the major interpretative gloss on Milton's Paradise Lost for it gave, as David Masson noted, "an indispensable commentary to some obscure parts" 4 of the poem. It is no wonder, therefore, that in 1991 William B. Hunter summarized the effect of his challenge of the treatise's Miltonic authorship as follows: "It is safe to say that lacking the thesis of This Great Argument Bright Essence would not exist and Milton's Brief Epic, Toward Samson Agonistes, and Milton and English Revolution would be quite different books from the ones we know." 5 The same is confirmed by John T. Shawcross in his answer to Hunter:

The suggestion that Milton may not have been the author of De Doctrina Christiana obviously has major implications for the study of his works, particularly of Paradise Lost, and of his beliefs. Denial of his authorship nullifies much of the scholarship of the last century and three quarters, or makes it redundant. ${ }^{6}$

The implications of Hunter's assertion, however, have reached far beyond "the last century and three quarters," for the debate on De Doctrina's provenance is still far from settled despite the great number of studies, articles and symposium panels dedicated to the matter. 7 As one of the participants noted, "the burden of proof is

trina Christiana and the Question of Authorship," Milton Studies 41 [2002] 172-230, p. 193). About the initial reception of the treatise see also Harry F. Robins, If this Be Heresy (Urbana: University of Illinois Press, 1963), pp. 5-6.

4. Christopher Hill, "Professor William B. Hunter, Bishop Burgess, and John Milton," Studies in English Literature 34 (1994) 165-193, p. 184.

5. William B. Hunter, "The Provenance of the Christian Doctrine," Studies in English Literature 32 (1992) 129-142, p. 129. Hunter here lists the most important classics in Milton scholarship written under the influence of Maurice Kelley's The Great Argument. These are: W. B. Hunter, C. A. Patrides and J. H. Adamson, Bright Essence: Studies in Milton's Theology (Salt Lake City: University of Utah Press, 1971); Barbara Lewalski, Milton's Brief Epic: The Genre, Meaning, And Art of "Paradise Regained" (Providence, RI: Brown University Press; London: Methuen, 1966); Mary Ann Radzinowicz, Toward "Samson Agonistes": The Growth of Milton's Mind (Princeton: Princeton University Press, 1978); and Christopher Hill, Milton and the English Revolution (London: Faber and Faber, 1977).

6. John T. Shawcross, "Forum: Milton's Christian Doctrine," Studies in English Literature 32 (1992) 155-162, p. 155 .

7. William B. Hunter delivered his challenge on 8 August 1991 to a session at the Fourth International Milton Symposium at the University of British Columbia, Vancouver, Canada. The main stream of the subsequent debate has been faithfully recorded on the pages of Studies in English Literature, although the articles contributing to the provenance of De Doctrina are 
on those affirming the attribution, not on Hunter, and until the matter of authorship is settled, the received wont of reading Paradise Lost or Milton's other works in light of De Doctrina Christiana stands on grounds less firm than before." 8

far from being contained in a single Journal. Chronologically these are the following: William B. Hunter, "The Provenance of the Christian Doctrine," SEL 32 (1992) 129-42, and in the same issue "Forum: Milton's Christian Doctrine," with responses by Barbara K. Lewalski (143-54), John T. Shawcross (155-162), and a counter-response by William B. Hunter (16366). Gordon Campbell, "The Authorship of De Doctrina Christiana," Milton Quarterly 26 (1992) 129-30. William B. Hunter, "The Provenance of the Christian Doctrine: Addenda from the Bishop of Salisbury," SEL 33 (1993) 191-207 followed by "Forum II: Milton's Christian Doctrine," SEL 34 (1994) with essays of Maurice Kelley, "The Provenance of John Milton's Christian Doctrine: A Reply to William B. Hunter" (153-64), Christopher Hill, "Professor William B. Hunter, Bishop Burgess, and John Milton" (165-94), and William B. Hunter, "Animadversions upon the Remonstrants' Defenses against Burgess and Hunter" (195-203). Gordon Campbell, Thomas N. Corns, John K. Hale, David I. Holmes, and Fiona J. Tweedie, "The Provenance of De Doctrina Christiana," Milton Quarterly 31 (1997) 67-117. Paul R. Sellin, "The Reference to John Milton's Tetrachordon in De Doctrina Christiana," SEL 37 (1997) 137-49. Also Paul R. Sellin, "John Milton's Paradise Lost and De Doctrina Christiana on Predestination,” Milton Studies 34 (1997) 45-6o. Again Fiona J. Tweedie, David I. Holmes and Thomas N. Corns, "The Provenance of De Doctrina Christiana, attributed to John Milton: A Statistical Investigation," Literary and Linguistic Computing 13 (1998) 77-87. Barbara K. Lewalski, "Milton and De Doctrina Christiana: Evidences of Authorship," Milton Studies 36 (1998) 203-28. "Responses" and "Further Responses" were issued by William B. Hunter and Paul R. Sellin, respectively, in Milton Quarterly 33 (1999) 31-37. Stephen M. Fallon, "Milton's Arminianism and the Authorship of De Doctrina Christiana," Texas Studies in Literature and Language 41 (1999) 103-27. Neil D. Graves, “"Here Let The Theologians Take Notice': A Note on the Provenance of Milton's De Doctrina Christiana,” Notes and Queries 46 (1999) 332-34. William B. Hunter, “De Doctrina Christiana: Nunc Quo Vadis?” Milton Quarterly 34 (2000) 97-101. Paul R. Sellin, "Some Musings on Alexander Morus and the Authorship of De Doctrina Christiana," Milton Quarterly (2001) 63-71. John T. Shawcross, "Milton and Of Christian Doctrine: Doubts, Definitions, Connotations," Explorations in Renaissance Culture 27 (2001) 161-78. Neil D. Graves, "Milton and the Theory of Accommodation," Studies in Philology 98 (2001) 251-72. Michael Lieb, "De Doctrina Christiana and the Question of Authorship," Milton Studies 41 (2002) 172-230. John K. Hale, "On Translating the De Doctrina Christiana," Milton Quarterly 37 (2003). See also books by William B. Hunter, "Visitation Unimplor'd": Milton and the Authorship of "De Doctrina Christiana" (Pittsburgh, 1998); Stephen B. Dobranski and John P. Rumrich eds., Milton and Heresy (Cambridge: Cambridge University Press, 1998); Kristin A. Pruit and Charles W. Durham eds., Living Texts: Interpreting Milton (Selinsgrove, PA: Susquehanna University Press, 2000), Barbara K Lewalski, The Life of John Milton: A Critical Biography (Oxford, UK; Malden, MA: Blackwell, 2000).

8. Paul R. Sellin, "John Milton's Paradise Lost and De Doctrina Christiana on Predestination," Milton Studies 34 (1997) 45-6o, p. 45. 
Encouraging further research for others, Hunter in his recent article puts forth a number of discrepancies between the treatise and the Milton oeuvre. My present paper focuses on one of these discrepancies, namely on "Dr. Sellin's distinction of differing interpretations of predestination." 9

$* * *$

In his article, “John Milton's Paradise Lost and De Doctrina Christiana on Predestination," Sellin suggests that an isolated "doctrinal issue" might be used as "a decisive limitus to determine whether the two documents [De Doctrina and Paradise Lost] are in fact as compatible as much scholarship maintains" provided that this issue is "large enough and central enough" 10 to both works in question. Building on Barbara Lewalski's response to William Hunter, ${ }^{11}$ Sellin further suggests that this "isolated doctrinal issue" be that of predestination.

Since by the second half of the sixteenth century, the doctrine of predestination had become a major point of controversy between Reformed, Lutheran, and Roman Catholic churches and had thus received a substantial elaboration in the hands of Reformed theologians and exegetes, ${ }^{12}$ there is no doubt that the treatise, and even the epic, addressed the issue. Sellin is therefore quite right in putting it forth as an issue of great importance, perhaps even of "decisive limitus," when comparing the compatibility of De Doctrina Christiana and Paradise Lost.

In order to compare the treatise's and the epic's stand on the problem Sellin gives a description of the standard orthodox Reformed views of predestination building on paradigms developed by the Dutch scholar Klaas Dijk. Accordingly, he examines each system in terms of (1) end, or purpose of the decree; (2) the position of predestination among other divine decrees preceding or following it; (3) the object of, or creature subject to the decree; and (4) the nature of the acts of election and reprobation that the decree entails.

Since the differences between De Doctrina Christiana and Paradise Lost in terms of end, object and nature of act are of minor importance, and mostly a

9. William B. Hunter, “De Doctrina Christiana: Nunc Quo Vadis?” Milton Quarterly 34 (2000) 97-101, p. 98.

10. Sellin, p. 45 .

11. Sellin quotes the following sentence of Lewalski: "in terms which recall De Doctrina I, ii-iv, Milton has God himself deny predestination. ..” (Sellin, p. 45).

12. For a comprehensive study on predestination in sixteenth and seventeenth century see Hans J. Hillerbrand ed., The Oxford Encyclopedia of the Reformation (New York; Oxford: Oxford University Press, 1996), Vol. 3, pp. 332-38. 
matter of wording, Sellin emphasises the "glaring" difference manifested in the position of predestination among other divine decrees preceding or following it, for as he states: "With respect of the order of decrees . . . the difference between Paradise Lost and De Doctrina Christiana is both essential and undeniable." 13 Namely, in Sellin's observation, the treatise places the decree of predestination before the Creation, whereas the epic puts the decree after the Creation but before the Fall of Man. Furthermore, by the same principle, Sellin also sees an "unbridgeable" gulf between Arminius and Paradise Lost, because in the view of James Arminius, according to Sellin, the decree of predestination comes not merely after the Creation, but also after the Fall of Man. ${ }^{14}$ Thus Sellin also denies the common assertion of Milton's Arminianism. ${ }^{15}$

Now let us see whether his assertion really stands firm under a close examination of the order of decrees in De Doctrina and Paradise Lost.

$$
* * *
$$

The treatise is quite explicit in its statement: "The principal special decree of God relating to man is termed predestination, whereby God in pity to mankind, though foreseeing that they would fall of their own accord, predestined to eternal salvation before the foundation of the world those who should believe and continue in faith. .." (43, my emphasis). ${ }^{16}$ Sellin argues that the expression "before the foundation of the world" locates the position of the decree of predestination as preceding both Creation and the Fall. Accordingly, "such a stand on sequence amounts to nothing less than classical supralapsarianism ${ }^{17}$ in that the decree of predestination precedes those effecting Creation and Fall, and it necessarily

13. Sellin, p. 52.

14. Sellin, p. 54 .

15. On the development of Milton's theological opinion from Calvinism towards Arminianism, as well as on predestination related to Milton see Barbara K. Lewalski, The Life of John Milton: A Critical Biography (Oxford, UK; Malden, MA: Blackwell, 200o), pp. 420-424; and Stephen M. Fallon, "Milton's Arminianism and the Authorship of De Doctrina Christiana," Texas Studies in Literature and Language 41 (1999) 103-27.

16. All parenthesised references are to this edition: The Prose Works of John Milton (London, 1891), Vol. 4, John Milton, A Treatise on Christian Doctrine, Compiled from the Holy Scriptures Alone: Book One, p. 43.

17. Supralapsarianism (or Ante-lapsarianism) is a form of Calvinistic doctrine of predestination which maintains that God decreed the election and non-election of individual men before the Fall of Adam. 
takes precedence over them." ${ }^{18}$ However, the expression is not decisive since it directly implies the words of Paul from the Epistle to the Ephesians chapter one, verse four: "Accordingly as he hath chosen us in him before the foundation of the world. .." 19 And, as Stephen M. Fallon correctly observes, "this biblical formula is common to all discussions of predestination in the period" and therefore fails "to distinguish between chronological priority ... and logical priority, on which the distinction between Arminianism and Calvinism depends." ${ }^{20}$ I would also like to emphasise that the treatise speaks only about the decree of predestination preceding the act of Creation, and does not assert an order of decrees whatsoever. In chapter three, concerning the divine decrees, the author of De Doctrina writes that "it is absurd to separate the decrees or will of the Deity from his eternal counsel and foreknowledge, or to give them priority of order" (30). The logic of this statement is drawn directly from the Scriptures, for if God knows "all his works from the beginning of the world," ${ }^{21}$ and that simultaneously, "according to his perfect foreknowledge of all things" (30) it is quite absurd to reason some kind of order of divine decrees resting upon a multidimensional foreknowledge of God.

In categorizing the treatise among the various trends of Reformation, the expression "foreseeing" is far more significant. Namely the act of foreseeing in predestining to "eternal salvation ... those who should believe and continue in faith" defies the treatise's Calvinistic form inasmuch as basing the predestination on divine foreknowledge of human virtue or merit would make the human condition, not the divine decree, the cause of salvation. This subordination, or coordination of the divine decree to human conditions is all but denied by Calvin and his followers. ${ }^{22}$ Later on I will return to the significance of the treatise's use of "foreseeing," but now let us see the order of divine decrees in Paradise Lost.

18. Sellin, p. 51.

19. King James Version of the Holy Bible (my emphasis).

20. Stephen M. Fallon, “'Elected above the rest': Theology as Self-representation in Milton," in Milton and Heresy, ed. Stephen Dobranski (Cambridge: Cambridge University Press, 1998), p. 98.

21. Acts 15:18 (King James Version of the Holy Bible).

22. For an exhaustive study on the development of the doctrine of predestination and its various trends see Jaroslav Pelikan, The Christian Tradition: A History of the Development of Doctrine (Chicago; London: University of Chicago Press, 1985), Vol. 4 (Reformation of Church and Dogma), pp. 217-244. 
In the epic poem we read the following setting of God's declaration:

Now had th' Almighty Father from above, From the pure Empyrean where he sits High Thron'd above all highth, bent down his eye, His own works and their works at once to view:

On Earth he first beheld

Our two first Parents, yet the only two Of mankind, in the happy Garden plac't, Reaping immortal fruits of joy and love, Uninterrupted joy, unrivall'd love In blissful solitude; he then survey'd Hell and the Gulf between, and Satan there Coasting the wall of Heav'n on this side Night In the dun Air sublime, and ready now To stoop with wearied wings, and willing feet On the bare outside of this World, that seem'd Firm land imbosom'd without Firmament, Uncertain which, in Ocean or in Air. Him God beholding from his prospect high, Wherein past, present, future he beholds, Thus to his only Son foreseeing spake.

$$
(3.56-59 ; 64-79)^{23}
$$

The setting is chronologically clearly defined: God the Father observes the already created "first Parents," "the only two of mankind," described in their prelapsus condition, i.e. prior to their Fall, "reaping immortal fruits of joy and love, / Uninterrupted joy, unrivall'd love / In blissful solitude." From this point of setting God the Father turns to his Son and relates the future disobedience of mankind, foreseen and not presently observed, and at the same time declares his purpose of grace towards them:

Man falls deceiv'd

By th' other first: Man therefore shall find grace, The other none: in Mercy and Justice both, Through Heav'n and Earth, so shall my glory excel, But Mercy first and last shall brightest shine. (3.130-134)

23. All parenthesised references to Paradise Lost are to this edition: Merritt Y. Hughes, ed., John Milton: Complete Poems and Major Prose (New York: Macmillan, 1989). 
Seemingly this setting confirms Sellin's assertion, but there are a few things that one has to take into consideration before drawing a conclusion. For convenience's sake I will not enter into a debate whether the declaration of the Father in Book Three is properly called Predestination as such, ${ }^{24}$ but it is important to note that here we are given merely "the moment that the decree is pronounced" 25 - a fact observed by Sellin himself. But as we continue reading, the following words of the Father put the decree into its proper position:

O Son, in whom my Soul hath chief delight,

Son of my bosom, Son who art alone

My word, my wisdom, and effectual might,

All hast thou spok'n as my thoughts are, all

As my Eternal purpose hath decreed:

Man shall not quite be lost, but sav'd who will,

Yet not of will in him, but grace in me

Freely voutsaft...

$$
\text { (3.168-175) }
$$

Here we read the Father's profession that the whole plan of salvation, the decree of grace towards the fallen mankind, was his "Eternal purpose" now only articulated and confirmed by the Son's reassurance of this purpose. So if we would want to erect an order of events as depicted in Paradise Lost it would be the following: (1) the "Eternal purpose" of the Father, that is, his decree of salvation or predestination (for predestination is but a decree related to the salvation of lost men); (2) the act, not the decree (for it is probably included into his eternal purpose as well) of Creation; (3) the proclamation of predestination before the "multitude of Angels" (3.345); and (4) the act of the already foreseen Fall. ${ }^{26}$ This of course erodes Sellin's assertion that Paradise Lost presents a remarkable "prelapsarian" position, as he calls it - i.e. setting the decree of predestination

24. The interpretation of the above mentioned quotation from Paradise Lost depends heavily on the preconditioned reading of the epic. To illustrate this it is enough to compare the conclusions drawn by Sellin, who reads it as a "short, simple, yet eternal decree of predestination," and by Stavely, who interprets it as a "prophecy, not decree.” See Sellin, p. 46; and Keith W. F. Stavely, "Satan and Arminianism in Paradise Lost," Milton Studies 25 (1989), p. 125 .

25. Sellin, p. 52.

26. I have deliberately omitted the events of Heavenly rebellion, Satan's voyage through Chaos, the warning of Adam, and a number of other events taking place in the epic, and reduced the order of events merely to those mentioned in Sellin's article. 
after the creation yet antecedent to the Fall - because it is not the decree itself that is positioned thus, but its utterance. Reading the epic it is quite clear that Milton strives not to "avoid the shoals of the 'supras' on the one hand and the rocks of 'infras' on the other" 27 by introducing a public declaration of the Father's intentions with the homo creatus et labilis, ${ }^{28}$ but is simply and yet magnificently dramatising the very end of the decree, namely, God's mercy which "first and last shall brightest shine" (3.134).

It seems to me, that the "glaring" difference between De Doctrina and Paradise Lost detected by Sellin is due only to the peril of treating the poem as it were a treatise and vice versa. As an author of the treatise, firmly resolved to "adhere to the Holy Scriptures alone" (8) leaving "as little space as possible might be left" for his own words (6) Milton would not be allowed "the kind of equivocation that marks Paradise Lost." 29 The author of the treatise must follow his own rule, demanded also by the genre of the treatise: "As to the actions of God before the foundation of the world, it would be the height of folly to inquire into them, and almost equally so to attempt a solution of the question" (169170). However, Milton as a poet will pursue "things unattempted yet in Prose or Rhyme" (1.16) and that not out of "folly" but out of mania, the folly of poets who are not only craftsmen of their art but also inspired to the words of poetry. So revisiting "with bolder wings" the "holy Light," he durst to sing "of Chaos and Eternal Night, / Thought by the heav'nly Muse to venture down / The dark descent, and up to reascend" $(3.13,18-20)$.

Being aware of the limits this paper enforces on an examination of theological matters, I have tried to find a quotation from the works of Arminius that would in a most explicit manner and clear reasoning present his views concerning the order of divine decrees thus allowing us a relatively simple comparison with De Doctrina and Paradise Lost.

The following statement is taken from Arminius' An Examination of the treatise of William Perkins Concerning the Order and Mode of Predestination:

27. Sellin, p. 52. "Supras" i.e. the supralapsarian view of predestination that claims the decree of predestination being issues before both the creation and before the Fall of Man, with sin a subsequent and necessary means to the end. "Infras" i.e. the infralapsarian view that puts the decree of predestination after, and not antecedent to, both the Creation and the Fall.

28. Homo creatus et labilis i.e. man that has already been created, not yet fallen, but capable of such fall.

29. Fallon, p. 96. 
I think, indeed, that both the creation, and the fall preceded every external act of predestination, as also the decree concerning the creation of man, and the permission of his fall preceded, in the Divine mind, the decree of Predestination. 30

At first glance it does look like a confession of an infralapsarian view, which asserts the decree of predestination following both the Creation and the Fall of Man, as Sellin asserts. But after a close examination of the statement we see that Arminius is emphasising the "external act of predestination" and "the Divine mind." That is, the action of both creation and fall precedes only the external act of predestination, and not the decree of it - although the decree concerning the creation of man, and the permission of his fall does precede, in the Divine mind, the decree of Predestination. Now if we would like to avoid a mistake prevailing "extensively on almost all religious questions, and is utterly subversive of candour and truth," $3^{1}$ that is, if we do not want to be biased by the use of words, it is essential to distinguish whether De Doctrina, Paradise Lost and Arminius speak of decrees or the acts of decrees.

To make the statement of Arminius even more explicit I would like to present a further expansion of his thoughts thus letting him interpret his own words.

Every act, which has reference to an object, is posterior in nature, to its object. It is called an object relatively. Therefore, it has an absolute existence prior to the existence of its relation to the act. The object, then, exists in itself, before it can be under the influence of the act which tends towards it. But man is the object of Predestination. Therefore, man is prior to the act of Predestination. But man is what he is by creation. Therefore, creation is prior to Predestination - that is, in the divine mind, or the decree concerning the creation of man is prior to the decree of Predestination, and the act of creation is prior to the execution of the decree of Predestination. If any one should reply that God, in the internal act of Predestination, is employed with man considered as not created, but as to be made, I answer that this could neither take place, nor be so understood by a mind judging rightly. For Predestination is a decree, not only to illustrate the divine

30. The Works of James Arminius (Albany, OR: Ages Software, 1997; v1.0), Vol. 3, James Arminius, An Examination of the treatise of William Perkins Concerning the Order and Mode of Predestination, p. 270.

31. John Brown and Edward Harold, An Exposition of the Thirty Nine Articles: Historical and Doctrinal (London: Longmans, 1878), p. 419. 
glory, but to illustrate it in man, by the mode of mercy and justice. From this, it follows that man must also exist in the divine mind before the act of Predestination, and the fall of man must itself, also, be previously foreseen. The attributes of God, by which creation is affected, are, therefore, considered as prior, in the divine nature, to those in which predestination originates. Goodness, simply considered, wisdom, and power, operating upon Nothing, are, therefore, prior to mercy and punitive justice. Add, also, that since predestination originates, on the one hand, in mercy, and on the other, in justice, in the former case having reference to salvation - in the latter, to damnation - it cannot be that any means exist pertaining, in common, to the execution of election and of reprobation. For they are provided neither in mercy, nor in justice. $3^{2}$

Here again an emphasis is clearly made distinguishing between the act and the decree of both Creation and Predestination: "creation is prior to Predestination - that is, in the divine mind, that is, the decree concerning the creation of man is prior to the decree of Predestination, and the act of creation is prior to the execution of the decree of Predestination" (my emphasis). To put it simply: the act of Creation is only prior to the execution of the decree of predestination but not to the decree itself. This of course does not seem to be an "unbridgeable gulf" between "the Dutch theologian" and Paradise Lost for nothing contradictory or even dissimilar is presented in the epic.

The reason why Arminius seems to juggle with the words "decree" and "act" is that he is trying to set not so much a chronological but rather a logical order of the divine decrees. His argumentation is directed against the assertions of the extreme Calvinism which from Theodore Beze onward posits a predestinationcentred theological approach to salvation. 33 This, so called, supralapsarian

32. Arminius, pp. 270-271.

33. Although the amount of space dedicated to predestination increased with each subsequent edition of his Institutes, Calvin vehemently denied predestination being the starting and thus the central point of his exposition of the certainty of salvation. However, it would be a mistake to associate supralapsarianism solely with the name of Beze. For although his views were more strictly patterned than Calvin's, and more indicative of the direction of later supralapsarianism, Beze did not argue an "order of the decree" in the manner of later supra- and infralapsarianism. Supralapsarianism as such is more a development of orthodox writers such as Amandus Planus, Francis Junius, Bartholomaus Keckermann, Johannes Scharpius, Lucas Trelcatius, Antonius Walaeus, Johannes Maccovius, and Franciscus Gomarus (the chief opponent of James Arminius), their teaching paralleling William Perkin's in England. For details see Pelikan, pp. 217-218; and The Oxford Encyclopedia, Vol. 3, pp. 335-37. 
view, gives an absolute priority to the decree of predestination from which all the other decrees stem from. As it also asserted the principal aim of the decree of predestination to display God's glory through the manifestation of mercy and justice Arminius felt it necessary to debate its priority for as he puts it:

It is certain that he [God] could not, first of all, have done this by means of mercy and punitive justice [i.e. to display his glory by issuing a decree of predestination]. For the former could be exercised only towards the miserable, the letter only towards the sinners. But since, first of all, the external action of God both was and must be taken up, so to speak, with Nothing, it is, therefore, evident that goodness, wisdom, and omnipotence were, first of all, to be unfolded, and that by them the glory of God was to be illustrated. These, therefore, were unfolded in creation, by which God appeared to be supremely good and wise, and omnipotent. 34

In other words: God must have created men first, at least in his thought, and foreseen their fall, before even thinking about how to manifest mercy and justice towards them that would at the same time display his own glory too. And since the act of predestination has reference only to fallen men, the execution of the very decree of predestination must follow both the act of Creation and of the Fall. 35

$$
* * *
$$

Now let us step back to De Doctrina for a moment. If Sellin's assertion is right, the gulf between the treatise and Arminius is even more unbridgeable than that between the Dutch theologian and Paradise Lost. We have already concluded that the treatise unmistakably puts the decree of predestination "before the foundation of the world," which, in Sellin's argumentation, leaves the act of both Creation and Fall in between the treatise's and Arminius' stand on the order of divine decrees. However the following argumentation from De Doctrina re-

34. Arminius, p. 265.

35. As a matter of fact, Arminius in his mature views argued, rather than a single eternal decree, four decrees and an order of priorities in the mind of God that rests on a distinction between an universal will to save and a consequent particular will directed toward believers. In the universal divine willing, a first eternal decree appoints Christ as the saviour of the human race in general, a second declares the divine intention to save in Christ all who repent and believe, and a third establishes the means of salvation. Then, and only then, a fourth decree, expressing God's consequent will concludes the salvation of the believers and the damnation of non-believers by foreseeing the choice of individuals to believe. See The Oxford Encyclopedia, Vol. 3, p. 337. 
markably corresponds to the arguments of Arminius in respect of the logical order of divine decrees:

It was not simply man as a being who was to be created, but a man as a being who was to fall of his own accord, that was the object of predestination; for that manifestation of divine grace and mercy which God designed as the ultimate purpose of predestination, presupposes the existence of sin and misery in man, originating in himself alone. (47)

There is of course a difference in wording (e.g. Arminius emphasising mercy and justice, whereas the author of the treatise mentions grace and mercy) but the logic of the argumentation is the same: the object of predestination can be only fallen, sinful man as mercy - the ultimate purpose of predestination - is justly endowed only if there is misery and sin involved. For Arminius this sets an order of divine decrees in which the decree of creation and the permission of fall precedes the decree of predestination. And although mentioning no set order, the author of the treatise does assert the same, when stating:

if God foresaw that man would fall of his own free will, there was no occasion for any decree relative to the fall itself, but only relative to the provision to be made for man, whose future fall was foreseen. (47)

Yet this statement makes him no infralapsarian, in the sense Sellin uses the word, nor denying the position of predestination being that "before the foundation of the world." Rather than that, we are simply witnessing an attempt of two theologians to rebuff the extreme Calvinist view of predestination. They are neither contradicting each other, nor are they by any means identical, for both are following a different path in argumentation. And when they are compared to Milton's Paradise Lost, there is no difference found between them in regard to what they hold about the position of the decree of predestination.

In addition, Sellin says that "the order of decrees has probably more to do with determining a theologian's stand on human 'liberty' than the other way around" and therefore attributes but a slight meaning to the issue of free will. But however good Sellin's suggestion of an "isolated doctrinal issue" sounds, it is impossible to treat any doctrinal issue as an isolated phenomenon, without including in the debate at least some of the relative doctrines of the theological system involved. Whether we like it or not, the doctrine of free will is, was and presumably will always be the counterpart of the doctrine of predestination. One could, of course, argue the inclusion of the relative concepts such as of sin, God, 
justification, and of certitude of faith - not to exhaust the list - but even without these we are in a danger of sharing the same fate with the group of fallen angels, who "apart sat on a Hill retir'd, / In thoughts more elevate, and reason'd high / Of Providence, Foreknowledge, Will and Fate, / Fixt Fate, Free will, Foreknowledge absolute, / and found no end, in wand'ring mazes lost" (2.557-61, my emphasis).

While the freedom of will was axiomatic for the theologians prior to the Reformation, ${ }^{36}$ all prominent Protestant reformers agreed with Luther's view that the doctrine of justification by faith alone implied the negation of free will in the fallen humanity. ${ }^{37}$ However, in Milton's poem free will is a recurrent issue, which is asserted and affirmed over and over again. So much so that it seems to constitute the essence of Paradise Lost. We read its powerful introduction in the speech of the Father relating man's foreseen Fall:

I made him just and right,

Sufficient to have stood, though free to fall.

Such I created all th' Ethereal Powers

And Spirits, both them who stood and them who fail'd;

Freely they stood who stood, and fell who fell.

Not free, what proof could they have giv'n sincere

Of true allegiance, constant Faith or Love,

Where only what they needs must do, appear'd,

Not what they would? what praise could they receive?

What pleasure I from such obedience paid,

When Will and Reason (Reason also is choice)

Useless and vain, of freedom both despoil'd,

Made passive both, had serv'd necessity,

Not mee. They therefore as to right belong'd,

So were created, nor can justly accuse

Thir maker, or thir making, or thir Fate;

As if Predestination over-rul'd

Thir will, dispos'd by absolute Decree

Or high foreknowledge; they themselves decreed

Thir own revolt, not I: if I foreknew,

Foreknowledge had no influence on their fault,

Which had no less prov'd certain unforeknown.

36. For example see Duns Scotus, Gregory of Rimini, Anselm, etc. (Pelikan, pp. 33-35).

37. See The Oxford Encyclopedia, Vol. 2, 141-46. 
So without least impulse or shadow of Fate, Or aught by me immutably foreseen, They trespass, Authors to themselves in all Both what they judge and what they choose; for so I form'd them free, and free they must remain, Till they enthrall themselves: I else must change Thir nature, and revoke the high Decree Unchangeable, Eternal, which ordain'd Thir freedom: they themselves ordain'd thir fall.

(3.98-128)

At this point I cannot but wonder why Sellin writes in reference to the above mentioned lines that "the passage quoted refers not, as the pronominal plurals make abundantly clear, to human 'liberty' but to that of the fallen angels." ${ }^{8}$ For as I see it, the pronominal plurals are not due to the reference to angelic host alone - for I wish not to deny their inclusion - but to the fact that God is foreseeing and relating not merely the fall of "Man" but as we read prior to the quoted passage: "So will fall / Hee and his faithless Progeny" (3.95-96, my emphasis). It seems also that angels and humans share not simply the Reason "differing but in degree, of kind the same" (5.490) - discursive being "oftest" humans' and the intuitive angels' "most" - but also the dower of freedom. For as we read, God made man "just and right, / sufficient to have stood, though free to fall" but also "such [He] created all th' Ethereal Powers / And Spirits, both them who stood and them who fail'd." So the divine bestowment of "liberty" was due to all, including humans and angels of all kind (see emphasis in the previous sentence) not reduced by any means to "the fallen angels" alone, as Sellin asserts. This is also confirmed by Satan's soliloquy when contemplating about the reasons of his rebellion he says:

Hadst thou the same free Will and Power to stand? Thou hadst: whom hast thou then or what to accuse, But Heav'n's free Love dealt equally to all?

$$
\text { (4.66-67) }
$$

The fact of man's freedom is again reinforced by the Father when sending Raphael to admonish Adam of his obedience, of his freedom, and the approach-

38. Sellin, p. 4 
ing danger in the shape of Satan. Thus he commissions Raphael with the following words:

such discourse bring on,

As may advise him of his happy state,

Happiness in his power left free to will,

Left to his own free Will, his Will though free,

Yet mutable.

(5.233-237)

Before listing further the instances where human freedom is repeatedly confirmed it is important to note the emphasis laid in these passages on the conditionality of divine decrees, a fact denied both by Hunter 39 and Sellin. ${ }^{40}$ For it is by emphasising the freedom of will that the conditionality of the divine decrees is established. As a matter of fact, when this emphasis of freedom is omitted Milton is careful to use if or while instead lest someone should miss the essence of the statement. Thus we read of the prospect of dwelling in earthly or "Heav'nly Paradise" conditioned by the following sentence: "If ye be found obedient, and retain / Unalterably firm his love entire / Whose progeny you are” (5.500-503).

So when we read again, in the words of Raphael directed to Adam, the confirmation of freedom being a general gift from God to all, we also witness the confirmation of the conditionality of divine decrees having the same general impact, equally manifested and efficient for both angels and men:

That thou art happy, owe to God;

That thou continu'st such, owe to thyself,

That is, to thy obedience; therein stand.

This was the caution giv'n thee, be advis'd.

God made thee perfect, not immutable;

And good he made thee, but to persevere

He left it in thy power, ordain'd thy will

By nature free, not over-rul'd by Fate

Inextricable, or strict necessity;

Our voluntary service he requires,

39. Hunter writes that the poem “ignores its [the treatise's] 'conditional decrees,' a basic position as the treatise redefines predestination in favor of Arminian views" (William B. Hunter, “The Provenance of the Christian Doctrine," SEL 32 [1992] 129-42, pp. 130-131).

40. Sellin, pp. 46-47. 
Not our necessitated, such with him

Finds no acceptance, nor can find, for how

Can hearts, not free, be tri'd whether they serve

Willing or no, who will but what they must

By Destiny, and can no other choose?

Myself and all th' Angelic Host that stand

In sight of God enthron'd, our happy state

Hold, as you yours, while our obedience holds;

On other surety none; freely we serve,

Because we freely love, as in our will

To love or not; in this we stand or fall.

$$
\text { (5.520-540, my emphasis) }
$$

And when one thinks it over carefully, there is no other way around. For if the will is free the decrees must be conditional, for if they were not, the will would be subjected to the inevitable, and the agent would be void of intelligence and reason ("Reason also is choice"), and thus without freedom "useless and vain" $(3.108,109)$.

Yet, there is one decree mentioned in Paradise Lost that seems to be unconditional, for as we read:

I form'd them free, and free they must remain, Till they enthrall themselves: I else must change

Thir nature, and revoke the high Decree

Unchangeable, Eternal, which ordain'd

Thir freedom.

$$
\text { (3.124-128, my emphasis) }
$$

The incongruity of free will and of unconditioned decrees thus seems to be reconciled in one single decree that unreservedly provides freedom to all. To deny the freedom from his creatures, angels or men, would also mean to "revoke" this "high Decree / Unchangeable, Eternal, which ordain'd / Thir freedom." But the fact that God provides another decree - the one he is articulating in the Book Three, and which would be eventually manifested in the act of salvation - shows that His intention is not that of revoking, but rather that of renewing:

once more I will renew

His lapsed powers, though forfeit and enthrall'd

By sin to foul exorbitant desires;

Upheld by me, yet once more he shall stand

On even ground against his mortal foe... 
Thus with a conditional decree of grace God reinforces the "high Decree" ordaining freedom to all men, and to the "Ethereal Powers and Spirits." As a matter of fact, the thoughts on free will in Paradise Lost are so consistent, that even the seemingly unconditional "high Decree" provides freedom only as long as this freedom is required - "free they must remain, / Till they enthrall themselves" which makes it, after all, a decree conditioned by the same freedom it provides.

Now, De Doctrina is emphasising the same importance of freedom and the conditionality of divine decrees because the author of the treatise is driven by the same imperative of theodicy as Milton and Arminius. Predestination and free will are both incorporated into a single argument of justifying "the ways of God to man" (1.26). In the poem, the rhetorical question of the Father, "whose fault? / Whose but his own?" $(3.96,97)$ introduces God's refuse of the foreseen, possible accusation to have caused man's Fall. Even the arch enemy, Satan, is left without just accusations in his soliloquy $(4.66,67)$. As for the treatise, there is an ostensible resemblance with the epic's argumentation:

God of his wisdom determined to create men and angels reasonable beings, and therefore free agents; foreseeing at the same time which way the bias of their will would incline, in the exercise of their own uncontrolled liberty. What then? shall we say that this foresight or foreknowledge on the part of God imposed on them the necessity of acting in any defined way? No more than if the future event had been foreseen by any human agent. ... nothing happens of necessity, because God has foreseen it; but he foresees the event of every action, because he is acquainted with their natural causes, which, in pursuance of his own decree, are left at liberty to exert their legitimate influence. Consequently the issue does not depend on God who foresees it, but on him alone who is the object of his foresight. Since, therefore, as has before been shewn, there can be no absolute decree of God regarding free agents, undoubtedly the prescience of the Deity (which can no more bias free agents than the prescience of man, that is, not at all, since the action in both cases is intransitive, and has no external influence,) can neither impose any necessity of itself, nor can it be considered at all as the cause of actions. If it be so considered, the very name of liberty must be altogether abolished as an unmeaning sound; and that not only in matters of religion, but even is questions of morality and indifferent things. There can be nothing but what will happen necessarily, since there is nothing but what is foreknown by God.

That this long discussion may be at length concluded by a brief summary of the whole matter, we must hold that God foreknows all future 
events, but that he has not decreed them all absolutely: lest the consequence should be that sin in general would be imputed to the Deity, and evil spirits and wicked men exempted from blame... . Thus God foreknew that Adam would fall of his own free will; his fall was therefore certain, but not necessary, since it proceeded from his own free will, which is incompatible with necessity. (39-41)

The very first lines almost echo the epic in its assertion that "Reason also is a choice." Namely, the fact that men and angels were created "reasonable beings" leaves no doubt with the author of the treatise that it logically and necessarily means that they are "free agents" as such.. The author then rebuffs the assertion that God's foreknowledge of their [that of the free agents'] action imposes a necessity upon them, for this would be incompatible with the notion of liberty. The conclusion drawn therefore is logical: there could be no absolute, unconditioned decree of God regarding free agents because: (1) it would abolish the name of liberty "as an unmeaning sound," and (2) it could serve as an excuse for "evil spirits and wicked men" for their sins by imputing sin in general to the Deity.

So, when compared to the epic, Book Three, lines 112-122, I cannot but agree with Barbara K. Lewalski's statement that "in terms which recall De Doctrina I.iii-iv, Milton has God himself deny predestination and insist his conditional decrees guarantee human liberty.” ${ }^{41}$

$* * *$

In the conclusion of his article, Sellin writes that the discrepancy between $D e$ Doctrina and Paradise Lost "touching predestination indicate that Hunter has put finger on a problem that is real." ${ }^{2}$ While I am not denying the problem I cannot see how the issue of predestination could be the indicator of it. As I have argued, the seeming difference Sellin detects between the treatise and Paradise Lost can be easily resolved when one takes into consideration whether the work under consideration speaks of the decree of predestination or the act of predestination, or of the Fall as happened or as just foreseen by God's omniscience. I hope I have sufficiently shown that the epic's so called prelapsarian view is by no means in contradiction with the view of the treatise, for it does not assert a decree of predestination positioned after the act of Creation and before the Fall of Man, but is dramatising the approaching danger of the adversary "whom no

41. Barbara K. Lewalski, "Forum: Milton's Christian Doctrine," SEL 32 (1992) 143-54, p. 150.

42. Sellin, p. 58 . 
bounds" can hold (3.81-84) and for that very reason articulating the "Eternal purpose" in front of a "multitude of Angels."

I have further hoped to show how inseparably the issue of predestination is linked with that of free will along with their joined imperative toward theodicy. In this matter I have also found De Doctrina being compatible with Paradise Lost, not differing from it in regard of the conditionality of the divine decrees, and of the emphasis laid on man's free will. And lastly, the mode in which the treatise and the poem argue God's integrity in the matter of the origin of sin bears such a resemblance to each other that it is hard indeed to think of any discrepancy between the two. 